\title{
NOVI PODACI O HVALOVOM ZBORNIKU
}

\author{
dr. sc. Ema Mazrak
}

Katedra za teoriju i historiju umjetnosti, Akademija likovnih umjetnosti Sarajevo, Sarajevo, Bosna i Hercegovina Department of the Theory and History of Fine Arts, The Academy of Fine Arts Sarajevo, Sarajevo, Bosnia and Herzegovina emazrak@gmail.com; e.mazrak@alu.unsa.ba

\section{Sažetak}

U članku se iznose rezultati istraživanja jednoga od najreprezentativnijih rukopisa srednjovjekovne Bosne - Hvalovog zbornika, obavljeni u Univerzitetskoj biblioteci u Bolonji. Sintetiziranim pregledom dosadašnjih istraživanja i komparativnom analizom originala i faksimilskog izdanja pokušalo se detektirati i re/intepretirati određene problemske cjeline vezane za Zbornik. Na prvom mjestu se ističe nova oprema kodeksa i način njegove pohrane u Biblioteci, a zatim se, kritičkim pristupom, valorizira originalni rukopis naspram faksimila. Posebno poglavlje je posvećeno rasporedu listova Hvalovog zbornika, saradnji dvojice minijaturista te tehnološkim aspektima iluminiranja.
\end{abstract}

Ključne riječi: Hvalov zbornik, Hval, original, faksimil, biblioteka, raspored listova, iluminacija

\section{Uvod}

Proučavanje Hvalovog zbornika (Biblioteca dell' Università di Bologna, Ms. 3575 B, 1404. g., skriptor Hval, dim. 170 x $110 \mathrm{~mm}$, pergament, 359 paginiranih listova) traje još od početka XIX stoljeća, tačnije od 1822, kada se u slavistici prvi put daju šturi podaci o ovom reprezentativnom kodeksu srednjovjekovne Bosne (Dobrowský 1822, 13). Veću pažnju stručne javnosti izazvalo je djelo Ivana Kukuljevića Sakcinskog (1857, 83-84), nakon čega slijede intenzivnije i različite analize (Rački 1869, 105-113; Daničić 1871, 1-146; Daničić 1872, 86109), a koje su aktualne još i danas. Primarni interesi stručnjaka uglavnom su se temeljili na:

1. Istraživanjima lingvističke, filološke i paleografske strukture kodeksa;

2. Pitanjima specifikuma autokefalne Crkve bosanske i historijskog okvira nastanka kodeksa;

3. Likovnom sadržaju Zbornika. ${ }^{1}$

Putem jezičkih analiza dolazilo se do novih spoznaja o ovom vrijednom spomeniku (Vrana 1942, 794-822; Hamm 1960, 43-104; Dragojlović 1981, 603-610; Dragojlović 1983a, 73-84; Dragojlović

Neki od autora/ica su problemu bosanskih rukopisa pokušali pristupiti interdisciplinarno. 1983a, 255-258; Kuna, Maksimović 1986; Dragojlović 1997; Jurić-Kappel 2002, 75-94; Nazor 2005, 540-541; Kuna 2008; MacRobert, Nakaš 2012; Nakaš 2018), međutim potrebno je sprovesti još dodatnih istraživanja, jer su stavovi autora/ica katkada u potpunosti oprečni, npr. u određivanju Apostola/ Praksapostola u Hvalovom zborniku ili porijekla tekstualnih matica za Apokalipsu. ${ }^{2}$

Ovaj kodeks je, između ostalog, pojedinim historičarima i teolozima služio kao argument u dugotrajnim raspravama o naravi Crkve bosanske. Preko njega su neki nastojali dokazati svoje pretpostavke o crkvi bosanskih krstjana bilo kao dualističkoj, bogumilskoj, odnosno crkvi - izdanku patarenskog heretičkog pokreta, bilo kao pravoslavnoj ili katoličkoj crkvi s istočnim obredom, a prisutne su i ideje o njoj kao benediktinskoj, ili, pak, šizmatičkoj, ortodoksnoj ili heterodoksnoj (Petranović 1867; Glušac 1924, 6-12; Glušac 1945, 120-125; Klaić 1927, 83-88; Solovjev 1948, 37-41; Petrović 1953; Mandić 1962; Šidak 1975; Dragojlović 1983, 73-

Godine 2018. izašao je članak "Katalog rukopisa bosanske crkvenoslavenske pismenosti" (Kirilometodievistika 12/18) Mehmeda Kardaša i Erme Ramić-Kunić sa, kako nam se čini, prilično neujednačenim (katkada i netačnim) navođenjem podataka o bosanskoj srednjovjekovnoj književnosti. Ovakvi sintetizirani prilozi su svakako dragocjeni, međutim, trebalo bi ih sustavnije i studioznije predstaviti. 
84; Malcolm 1995; Šanjek 2000, 423-429; Šanjek 2003; Ćošković 2005; Lovrenović 2000, 257-294; Džaja, Lovrenović 2005, 3-15; Lovrenović 2006; Fine 2005; Brković 2008; Petrović 2008; Filipović 2017). S obzirom na složenost pitanja koja se odnose, prije svega, na crkveno-historijske okvire sakralne književnosti srednjovjekovne Bosne, a samim tim i Hvalovog zbornika, odgovori na mnoga su ostali otvoreni i danas.

Unatoč brojnim istraživačkim radovima, likovni repertoar ovog kodeksa, veoma kompleksan i ikonografski zanimljiv, nije sustavnije proučavan (Radojčić 1950, 44-45; Muzzioli 1954, 19; Đurić 1957, 39-51; Maksimović 1976, 175-188; Nikolajević 1977, 75-77; Maksimović 1983, 64-65, 115116; Maksimović 1986, 22-29; Harisijadis 1988, 91-143; Maksimović 1997, 53-70; Mikulić 2004; Mazrak 2016, 17-50). ${ }^{3}$ Najveći doprinos na ovom polju dali su autori Vojislav Đurić i Jovanka Maksimović.

Kao što je već poznato, rukopis je dospio u Univerzitetsku biblioteku u Bolonji 6. IX 1755. g. kao poklon pape Benedikta XIV (1740-1758), koji ga je dobio od talijanskog lingvista, erudita, filozofa i profesora Univerziteta u Padovi Giacoma Facciolatija (1682-1769) (Biblioteche d'Italia 1991, 23-33). Prvotno je pripadao fondu Benedikta XIV (Fondi Benedetto XIV.), a nekolicina ga je talijanskih istraživača u vrlo kratkim informativnim crtama spominjala prilikom osvrtâ na rukopisnu građu koja se čuva u ovoj biblioteci (Rodriquez 1956, 139; Antonino 2004, 30). Kodeks je gotovo potpuno očuvan, uključujući i kolofon (fol. 359r). ${ }^{4}$ List ispred kolofona nedostaje, tako da se posljednja pjesma "Bogorodičin kantik" prekida na stihu 68, s tim da postoje pretpostavke kako je prilikom novog uvezivanja došlo do premetanja listova 17 i 18 (Kuna, Maksimović 1986, 13). Dvostupačnog je teksta, pisan poluustavom karakteristične bosanske redakcije crkvenoslavenskog, sitnijim slovima. ${ }^{5} \mathrm{Na}$ temelju analiza leksike i sintakse, te djelomično i fonologije i morfologije, ustanovljeno je kako mu je kao pisana matrica poslužio neki arhaičan glagoljski predložak ohridske arhiepiskopije, što se očituje i u prisutnosti nekoliko glagoljskih slova/brojeva (fol. 102, fol. 106) i fondu leksema (Kuna 2008, 161-163). U ikaviziranom tekstu razmjerno inovirane fonologije

3 U člancima/knjigama autorica J. Maksimović, M. Harisijadis i P. Mikulić Hvalov zbornik se istražuje u sklopu integralnog pregleda srednjovjekovnih bosanskih rukopisa. Rezultati istraživanja su sadržani najčešće na nekoliko kartica teksta.

4 Veoma su dragocjeni podaci sadržani u kolofonu: godina nastanka, imena pisara i rubrikatora Hvala, poglavara Crkve bosanske djeda Radomira i Hrvoja Vukčića Hrvatinića kome je kodeks posvećen.

5 Godine 1986. Zbornik je izašao u faksimilskom izdanju (Kuna, Maksimović 1986), te je na taj način postao dostupan široj stručnoj javnosti. prisutni su utjecaji tadašnjega narodnog govora, a dijalekatski se vezuje za jugozapadnije štokavsko područje. Tekst karakterizira mehaničko dijeljenje riječi na kraju redaka (scriptura continua), kao i odsutnost znakova interpunkcije. Ispisan je pretežno tamnosmeđom, a mjestimično smeđom tintom $\mathrm{s}$ primjesama sepije, a podnaslovi (rubrike), marginalne bilješke i inicijali zlatom i crvenom. ${ }^{6}$ Pisani sadržaj kodeksa je sljedeći: 1. Euzebijeva poslanica Kiprijanu, 2. Kanonske table, 3. Četiri evanđelja kojima prethodi popis glava, 4. Sinopsis PseudoAtanasija o simbolima evanđelista, 5. Apokalipsa, 6. Dekalog, 7. Poslanica Doroteja episkopa Tirskog o sedamdeset učenika/apostola Božjih, 7. Poslanica svetoga Epifana Kipranina o dvanaest svetih apostola, 8. Obhoždenije Pavla apostola, 9. Mučenije Pavla apostola, 10. Kraći prolog Djela apostolskih bez naslova, 11. Napisanije glavi Djela apostolskih, 12. Historija Djela apostolskih, 13. Djela apostolska, 14. Apostolske (katoličke) poslanice kojima prethode popisi glava, 15. Prvo slovo Pavla apostola i dva kratka egzegetska teksta o poslanicama sv. Pavla, 16. Pregled i popis glava i stihova Pavlovih poslanica, 17. Pročrtanie, 18. Pavlove poslanice s popisom glava, 19. Psalmi Davidovi, 20. Devet biblijskih pjesama i 21. Kolofon.

Rukopis ima ukupno trinaest cjelostraničnih minijatura, trinaest manjih ili većih integriranih u tekst, Euzebijevu poslanicu Kiprijanu uokvirenu na isti način kao i deset kanonskih tabli, šest zaglavlja različitih tipova, deset velikih raskošnih inicijala, dva inicijala s ljudskom figuracijom te niz srednjih i manjih inicijala, zastavica i drugih slikanih ukrasa. Oslikala su ga dvojica minijaturista: krstjanin Hval i minijaturista iz Splita.

Imali smo priliku pogledati i proučiti original u Univerzitetskoj biblioteci u Bolonji, pa ćemo stoga iznijeti neke podatke koji se do sada u cjelokupnom pregledu literature ne spominju. ${ }^{7}$

\section{Kodikološka / komparativna analiza - original i faksimil Hvalovog zbornika}

Kako je to već naznačeno u prethodnim analizama autora koji su se bavili istraživanjem Hvalovog zbornika, originalni uvez nije sačuvan. Uvez od tamnosmeđe kože sa zlatnim slovima na hrptu / TEST. NOVUM DOROTH.. DE LXXII. DISCIPUI PSALTER. CAN TICA./, podudaran sa faksimilskim izdanjem, stavljen je vjerovatno po dopremanju u Biblioteku. Premda je Zbornik nanovo uvezan još 1987. godine, niti jedan autor/ica to ne spominju

\footnotetext{
Marginalne bilješke nastale su istodobno s glavnim tekstom.

7 Željela bih se zahvaliti izuzetno ljubaznom i profesionalnom osoblju Odjela za rukopise Univerzitetske biblioteke u Bolonji, koji su mi ustupili sav potreban materijal za rad.
} 
(slike 1, 1a). Samim tim, pretpostavljamo da su se u svojim analizama služili faksimilskim izdanjem objavljenim 1986. godine. ${ }^{8}$ Stari, prilično oštećeni i dijelom otrgnuti uvez sada je arhiviran uz kodeks u posebnoj kutiji gdje je pohranjen. Na unutarnjoj strani zadnje korice Zbornika je pečat firme koja je radila novi uvez - Castrignano, Bologna.

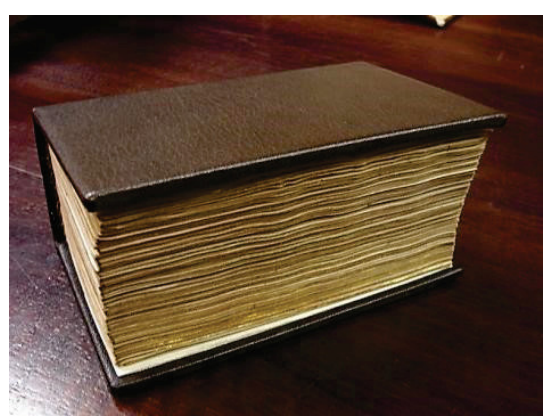

Slika 1a. Novi uvez Hvalovog zbornika

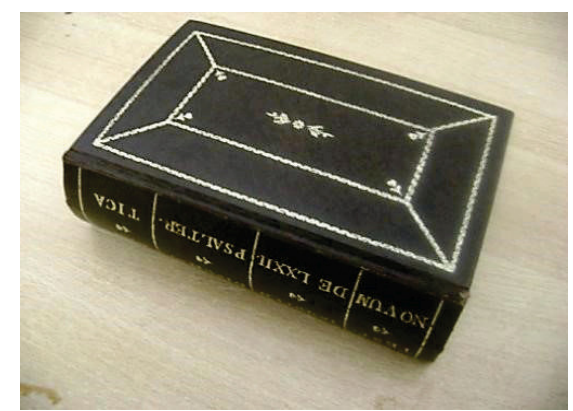

Slika 1b. Stari uvez Hvalovog zbornika u faksimilskom izdanju

Novi uvez od tamnosmeđe kože bez ikakvih je natpisa. Naime, 1987. je izvršena konzervacija i restauracija rukopisa kada su, osim stavljanja uveza, drugačijim redoslijedom smještene i uvezane stare opservacije bibliotekara, a između minijatura umetnuti bijeli listovi papira zbog njihovog očuvanja. ${ }^{9}$ Papir nelogično nedostaje između minijaturâ "Blagovijesti" i "Sv. Mateja evanđeliste i njegovog simbola krilatog čovjeka (Imago hominis)" (fol. 13v i 14r).

Uvidom u original i komparativnom analizom ustanovili smo da se u odnosu na njega faksimilsko izdanje znatno razlikuje. Prilikom izrade faksimila tekst je, zajedno sa minijaturama, povećan u odnosu na original. Proporcionalno uvećanju cijelog štampanog lista, koje iznosi oko $1 \mathrm{~cm}$ po visini, a oko $0,7 \mathrm{~cm}$ po širini, i minijature su povećane za nekoliko milimetara. ${ }^{10}$ Zbog ovakvog uvećanja, prouzročenog vjerovatno greškom prilikom pripre-

\footnotetext{
8 Čak ni glavna urednica faksimilskog izdanja Herta Kuna u svojim člancima novijeg datuma ne iznosi nikakve podatke o novoj opremi Hvalovog zbornika. U njenoj uvodnoj studiji faksimila navodi da je tadašnji uvez "jednim dijelom odvaIjen" (Kuna, Maksimović 1986, 12).

9 Papiri su za oko pola cm manji od formata listova. U Biblioteci nismo našli nikakve pisane tragove o konzervatorskorestauratorskom zahvatu izvršenom na Hvalovom zborniku.

10 Dimenzije gornjih margina također često nisu iste.
}

me materijala za štampu, a kako se nastojalo pratiti izvornik u formatu listova od 170 x $110 \mathrm{~mm}$ rezane su margine na kojima je paginacija, kao i one bočno. Tako u faksimilu na nekim listovima paginacije uopće nema ili je vidljiv samo njezin gornji dio, dok je na originalu paginacija jasno vidljiva, a margine su šire.

Kao primjere ističemo dimenzije margina u originalu i faksimilu na fol. 5r: donja margina originala je 3,7 , a faksimila $2,7 \mathrm{~cm}$, te fol. $4 \mathrm{r}$ - bočna margina originala je 2 , $\mathrm{u}$ faksimilu $1,3 \mathrm{~cm} /$ donja margina $\mathrm{u}$ originalu 3,8 , a faksimilu $2,8 \mathrm{~cm}$. Jasno je da se radi o velikom propustu kojim se mijenja izvorni izgled kodeksa, a istodobno potiče i na donošenje krivih zaključaka kako su u bolonjskoj biblioteci listovi kodeksa "srezani" baš kao i u faksimilu, jer se podrazumijeva da faksimil odgovara stvarnom stanju.

Pažljivim proučavanjem došli smo do zaključka da je dobar dio listova već prilikom prvog uvezivanja $\mathrm{u}$ biblioteci pomjeren gore ili dolje, a i prilikom njihovog rezanja, koje je evidentno, odrezan je dio s oslikom (npr. na listu 14r, gdje nedostaju vrhovi pobočnih kula minijature). Kako se čini, listovi su rezani za samo nekoliko milimetara, ali toliko je dovoljno da se izgubi autentičan izgled i cjelovitost iluminiranih stranica. Ako su u današnjici dimenzije kodeksa 170 x $110 \mathrm{~mm}$, onda je izvorno kodeks bio bar nekoliko milimetara veći.

Po šest bifolija vezano je koncem u sveščiće od po dvanaest listova, seniona. $\mathrm{S}$ vanjske strane svi listovi rukopisa premazani su zlatom. Koža uveza je dobro nategnuta i s unutrašnje strane prekrivena žućkastim papirom, prvi list je bez paginacije, samo je u gornjem desnom uglu olovkom napisana signatura 3575 B. Iza ovog prvog lista slijede još tri blan$k o$ od istoga papira (posrijedi je novija oprema rukopisa), a zatim list papira starijeg datuma, kraći za oko $5 \mathrm{~mm}$ u donjem dijelu, na kojem su smećkaste mrlje i dvije rupice u donjem desnom uglu. U kodeks je uvezan i papirni list starijeg datuma sa smeđim mrljama formata A4 (podrezan s lijeve strane po dužini do pola, presavijena mu je donja trećina, a i tri puta po širini kako ne bi stršio vani). Na tom je papiru neko iz Univerzitetske biblioteke ispisao perom dijalektalnim talijanskim(?) kratke bilješke o rukopisu u gornjem dijelu u četiri reda, a ispod, u dva stupca, pregled svetaca kalendara za januar usporedno na latinici i staroslavenskom srpske redakcije. ${ }^{11}$ Nepoznato je zbog čega popis svetaca za januar autor ovoga popisa povezuje sa Zbornikom

\footnotetext{
11 S obzirom na to da nije riječ o latinskom, nego prije o dijalektalnom talijanskom, što bi se trebalo dodatno ispitati, iznosimo pisani sadržaj prije usporednog pregleda svetaca: Est / traiuctie inscriptionis lingua illirica litaralis inlatinam, posita ae imaginam pictam qua est duode(cima) / pars calendarij Grecorusi festivitatum de praupto, ve / presentata initium Anni justastitu pegoriam calendarij nempe jannuar.
} 
jer u njemu nema niti kalendara niti svetaca koji se za njega vezuju, a na stranici je u gornjem lijevom uglu olovkom ispisana i signatura kodeksa, dakle, trebalo bi da se odnosi na naš rukopis. Na sljedećoj blanko stranici sa žućkastim i smeđim mrljama u donjem desnom uglu olovkom je ispisano rimsko "I". I naredna ima rimsko "II" na istome mjestu, s tim da je na verso strani u gornjem lijevom dijelu crnim perom opet tanko ispisana signatura. Slijede dva blanko lista nejednakih formata, a na zadnjem je u donjem desnom uglu rimsko "III".

Prva paginirana strana nalazi se na listu pergamenta: u gornjem središnjem dijelu ima olovkom ispisanu signaturu, u središtu ovalni pečat biblioteke, a dolje također pravougaoni pečat sa signaturom. Folijacija cijeloga kodeksa, negdje i dupla, u donjem desnom uglu listova arapskim brojkama, na originalu se vrlo jasno vidi, dok je na faksimilu potpuno ili djelimično odrezana. ${ }^{12}$ Zadnji paginirani list je 359 , a na njemu se ispod kolofona koji završava na sredini lijevoga stupca nalazi ovalni pečat biblioteke, te na verso strani pravougaoni sa signaturom. Iza zadnjeg paginiranog lista uvezana su dva starija lista bibliotekara (opet formata A4 i presavijena) s pobrojanim dijelovima Zbornika bez Apokalipse na talijanskom i kolofon na latinskom. Ispod kolofona tog spisa je novija bilješka o Daničićevom objavljivanju rukopisa u Starinama JAZU (III; 1871) i godina nastanka Zbornika. Iza ovih su još dva novija lista, jedan s obilježenim rimskim "IV" olovkom, u donjem i u gornjem desnom uglu opet naziv biblioteke u plavom dvostrukom okviru.

Kodeks dakle broji, ako izuzmemo dodane spise i papire umetnute između iluminiranih stranica, 359 paginiranih, a zajedno s umetnutim s početka i kraja 369 listova. ${ }^{13}$ Skriptor Hval je kodeks numerisao na središnjim dijelovima donjih margina, a numeracija, koja je izvršena na svakom osmom listu verso strane (s jednim izuzetkom), počinje na fol. $28 \mathrm{v}$, i to s brojem 2 ("B"), a završava na 358v brojem 43 ("МГ"). ${ }^{14}$

U Zborniku su evidentna mehanička oštećenja pergamenta. Tako je list 7, s Euzebijevom poslanicom Kiprijanu, sa strana mašinski probijen s četiri pravilne rupice. ${ }^{15}$ Po jedna se nalazi na listovima 1,2 ,

12 Trostruka je paginacija lista 202r: u donjem desnom uglu iznad broja 202 prekrižen 203, a broj 202 je ispisan i u gornjem desnom.

13 Herta Kuna u predgovoru faksimilskog izdanja navodi da kodeks broji 364 lista od kojih je 359 paginirano (Kuna, Maksimović 1986, 13).

14 Numerisani su listovi: 28v, 36v, 44v, 52v, 60v, 68v, 76v, 84v, $92 \mathrm{v}, 100 \mathrm{v}, 108 \mathrm{v}, 116 \mathrm{v}, 124 \mathrm{v}, 132 \mathrm{v}, 140 \mathrm{v}, 148 \mathrm{v}, 156 \mathrm{v}, 164 \mathrm{v}$, $172 \mathrm{v}, 180 \mathrm{v}, 188 \mathrm{v}, 196 \mathrm{v}, 204 \mathrm{v}, 212 \mathrm{v}, 220 \mathrm{v}, 228 \mathrm{v}, 236 \mathrm{v}, 246 \mathrm{v}$, $262 \mathrm{v}, 270 \mathrm{v}, 278 \mathrm{v}, 286 \mathrm{v}, 294 \mathrm{v}, 302 \mathrm{v}, 310 \mathrm{v}, 318 \mathrm{v}, 326 \mathrm{v}, 334 \mathrm{v}$, $342 \mathrm{v}, 350 \mathrm{v}$ i $358 \mathrm{v}$. Iz ovoga slijeda se vidi da je izuzetak samo raspon između listova $236 \mathrm{v}$ i $246 \mathrm{v}$.

15 Ova oštećenja se ne vide u faksimilu, a u izvorniku su na unutarnjim ili vanjskim marginama.
3 i 4 na samoj ivici vanjske margine, dvije su na listu 8 , kao i dva polukružna oštećenja nastala od iste sprave, na listu 9 također su dvije rupice i jedan polukrug, na 10 i 11 dvije rupice i na 12 jedna na vanjskom rubu bočne margine. Pojedini listovi imaju manja oštećenja, npr. fol. 47 je s oštećenjem na ivici od svega nekoliko milimetara ili fol. 132 poderan na vanjskoj margini i sašiven koncem.

Premda bi se Hvalov zbornik trebao sustavnije istražiti savremenim sredstvima kodikološke analize, upotrebom povećala opazili smo kako je pergament nedovoljno očišćen prilikom pripreme za rad. Primjetni su tragovi grublje teksture kože s korijenom dlake na većem broju listova (npr. na fol. 1, 2, $3,4,5,6,13,38,42,47,48,69,85,88,91,92,94$, $141,151,152,163,197,198,202,204,221,222$, 243, 265).

Izuzev oštećenja prilikom iluminiranja, nedovoljnog sušenja boje (prvi dio kodeksa) i neadekvatnog omjera veziva u spravljanju tekućeg zlata, kao i pregustih nanosa pigmenta/zlata koji su rezultirali ljuštenjem na nekim partijama oslika, evidentna su i manja oštećenja kodeksa prouzrokovana vanjskim faktorima. ${ }^{16}$ Tako se uočavaju manji tragovi vlage na mjestima gdje se bifoliji vezuju s hrptom (fol. 3 i $4,5,12,13,69,70,132,133,212,213$ ), a pretpostavljamo da su restauratori rukopisa i iz tog razloga stavili papirnate listove između folija radi zaštite. Znatnija oštećenja u vidu ljuštenja boje, žutila i vlage vidljiva su na listovima 162 i 163 . Na verso strani fol. 163 prisustvo vlage očituje se u vidu široko postavljenih mrlja plavičastog inkarnata. Neki od listova dobili su žućkasto-smećkasti fon ili su naborani zbog neadekvatne zaštite, $i$ to uglavnom u prvom dijelu rukopisa, kao i na listovima s minijaturama. Samim tim, može se zaključiti kako su upravo ti listovi bili najviše izloženi vanjskim uticajima, te kako je početak Zbornika određeni vremenski period bio neuvezan. Premda su minijaturisti koristili kvalitetne pigmente za rad, kao i zlato na dva načina (Hval) - tekuće i zlato u listićima, uočavamo nejednaku kvalitetu u interpretaciji. Na minijaturama koje su se slikale brže opažaju se kapljice boje ili zlata po pergamentu (na nekim mjestima boja je razmazana), a također i kapljice voska(?) na listovima 166, 169, 173, 238.

Ljuskanje boje, tj. odvajanje boje od podloge/pergamenta, može imati nekoliko uzroka: neodgovarajući način rada iluminatora (količina i koncentracija veziva, neadekvatna priprema podloge, higroskopna svojstva pergamenta, debljina bojenog nanosa itd.); elastičnost nosioca/podloge nasuprot krtosti polimenta (primarnog veziva pozlate) također može prouzrokovati pojavu pukotina - krakelira; stalna upotreba rukopisa, učestalo prevrtanje listova; vanjski faktori poput vlažnosti zraka i sl. (Radosavljević 1984; Kreigher-Hozo 2007, 202, 208). 


\section{Iluminacija u originalu i faksimilu}

Uspoređujući iluminaciju u originalu i faksimilu nalazimo da su često i boje znatno drugačije u nijansama, napose plava i zelena koje su uglavnom tamnije i intenzivnije, kao i svijetloljubičasta koja ima hladni ton, a ne topli. Neke od boja uopće ne ilustruju izgled vjerno, poput svijetloljubičaste $\mathrm{u}$ faksimilu, koja je u izvorniku plava ili sivkastoplava (npr. donji dio minijature "Blagovijesti", tijelo krilatog lava, simbola sv. Marka i sl.). Osim toga, teksture na zlatnim površinama pojedinih minijatura i inicijala uopće se ne vide, a u izvorniku su veoma bogate i minuciozno rađene, $\mathrm{s}$ križnim šrafurama, tačkicama, zvijezdama itd. Navest ćemo samo nekoliko primjera. Minijatura krilatog lava, simbola sv. Marka (fol. 47v), ima reljefnu zlatnu apstraktnu pozadinu dekorisanu na dva načina - u donjoj zoni $\mathrm{s}$ romboidnom mrežom i tačkicama, a u gornjoj $\mathrm{s}$ veoma gustom šrafurom kosih crta. Ovakav minuciozan rad jedva se nazire $u$ faksimilskom izdanju. $\mathrm{Na}$ minijaturi sa sv. Lukom evanđelistom i njegovim simbolom (fol. $69 \mathrm{v}$ ) punciranje na zlatnim partijama se ne vidi, boje su izražajnije i dubljih tonova, a dio krila na vanjskoj margini koja su u faksimilu srezana, u izvorniku su skladno smještena unutar lista. Zlatna pozadina reljefno izvedene teksture na minijaturi sa sv. Ivanom evanđelistom i njegovim simbolom orlom (fol. 106r), u gornjem dijelu izvedena karakterističnim mrežastim uzorkom s tačkicama, a u donjem, unutar nešto većih rombova, s "ugraviranim" zvjezdicama i rozetama sa šest ili osam latica, $u$ faksimilu je slabo vidljiva i to samo na nekim mjestima.

Proučavanjem originala došli smo i do određenih zaključaka glede izvornog i sadašnjeg rasporeda listova u kodeksu.

\section{Izvorni slijed listova u Hvalovom zborniku - analiza}

U dosadašnjim istraživanjima Hvalovog zbornika, ako izuzmemo Hertu Kunu i njezina zapažanja da je došlo do premetanja listova 17 i 18, jedina autorica koja je uočila da su listovi bili drugačijeg rasporeda u izvornom obliku ovog kodeksa bila je Jovanka Maksimović (1983, 116; 1986, 25). Ona je pretpostavljala da se tzv. minijaturni poliptih prvog minijaturiste (listovi s dvanaest apostola, sv. Ivanom Krstiteljem, "Kristom u slavi", "Raspećem" i "Bogorodicom s djetetom" na samom početku rukopisa od fol. $1 \mathrm{v}$ do fol. $6 \mathrm{r}$ ) nalazio iza četveroevanđelja ili Djela apostolskih. Autorica je također istakla da su ti listovi ubačeni naknadno te da je jedino moguć bio takav raspored ruku majstora kako je predložila. Saglasni smo s mišljenjem da je Zbornik trebao počinjati kanonskim tablama kao što se našim istraživanjima i potvrdilo, ali J. Maksimović nije uzela u obzir da se oslik rukopisa radio na bifolijima, tako da je nemoguće da su ovi listovi ubačeni naknadno, jer su fizički vezani za iluminaciju s kanonskim tablama.

Nedovoljno osušena boja, ali i vezivo kojeg je Hval previše stavljao prilikom pripreme tekućeg zlata, ostavili su traga na susjednim listovima, pa smo na taj način, putem tragova otisaka boje ili veziva, ustanovili sasvim drugačiji izvorni raspored u Zborniku od onoga koji je Maksimović predložila.

$\mathrm{Na}$ osnovi detaljne analize zaključujemo kako je došlo do premetanja listova u prvom dijelu kodeksa - "minijaturnog poliptiha" i Euzebijeve poslanice Kiprijanu s kanonskim tablama, odnosno šest bifolija s početka koji su naopako povezani. Budući da je pojava ovakvog "minijaturnog poliptiha" izuzetak u knjižnom slikarstvu srednjovjekovne Bosne, a kanonske table se gotovo u pravilu javljaju na samom početku kodeksâ, tako je i predloženi raspored listova svakako logičniji. Usporedba kanonskih tabli u Hvalovom moguća je jedino još s onima u Mletačkom zborniku (Biblioteca Nazionale Marciana, Venezia, Cod. Or. $227=[168])$, veoma značajnom rukopisu srednjovjekovne Bosne.

Dakle, izvorni raspored listova u Hvalovom zborniku počinjao je Euzebijevom poslanicom i kanonskim tablama (Hval), zatim je slijedio "minijaturni poliptih" (splitski minijaturista), nakon kojeg opet radi Hval. Na stranici iza ovog "poliptiha" on slika svoj autoportret $\mathrm{u}$ inicijalu unutar zastavice i nastavlja oslikavati kodeks sve do početka Ivanovog evanđelja (fol. 106r) - ta minijatura je rad obojice minijaturista, a one na listovima koji slijede sve do kraja kodeksa djelo su splitskog majstora. S tim u vezi bitno je istaknuti da je sva zaglavlja, zastavice i inicijale u cijelom rukopisu izvodio Hval. On je također potpisivao radove splitskog minijaturiste.

Ovaj novi poredak listova ustanovljen je temeljem otisaka na fol. 1r na kojem se vide dijelovi kanonske table s lista $12 \mathrm{v}$ (slike $2,2 \mathrm{a}$ ), te $6 \mathrm{v}$ s otiskom dijela figuralnog inicijala s lista 13r (slike 3, 3a).

\section{Zaključak}

Analizom Hvalovog zbornika i njegovom komparacijom sa faksimilskim izdanjem zaključujemo kako je došlo do određenih propusta prilikom objavljivanja faksimila, ponajprije u vidu tehničkih grešaka i kvalitete reprodukcija. S druge strane, original rukopisa se čuva u adekvatnim uslovima, znatnijih oštećenja nema, a u dva navrata je na korektan način sprovedena njegova konzervacija i restauracija. Premda su uočeni tragovi brzog slikanja, nedovoljnog sušenja ili ljuštenja boje, ispisani i iluminirani listovi još uvijek izgledaju svježi i sjajni, što svjedoči o djelu dobro educiranih srednjovjekovnih majstora. Otkriveni poredak listova je vrlo važan pri proučavanju rada i saradnje dvojice iluminatora, a 


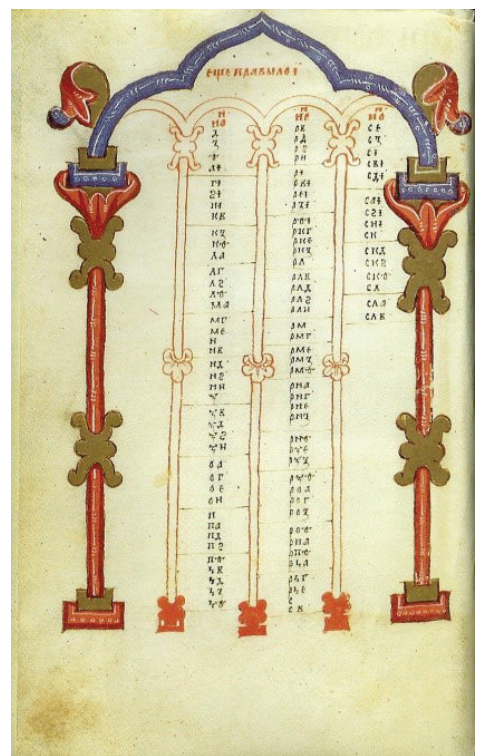

$2 a$

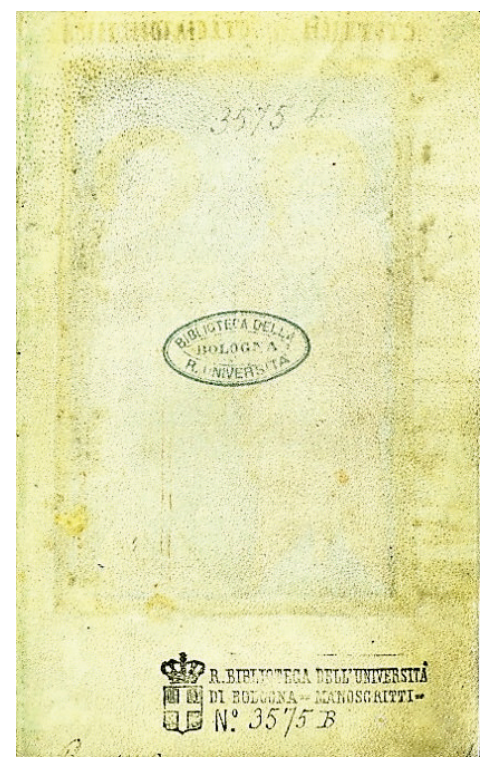

$2 \mathrm{~b}$

Slika 2. Otisak kanonske table sa $12 r$ na $1 r$

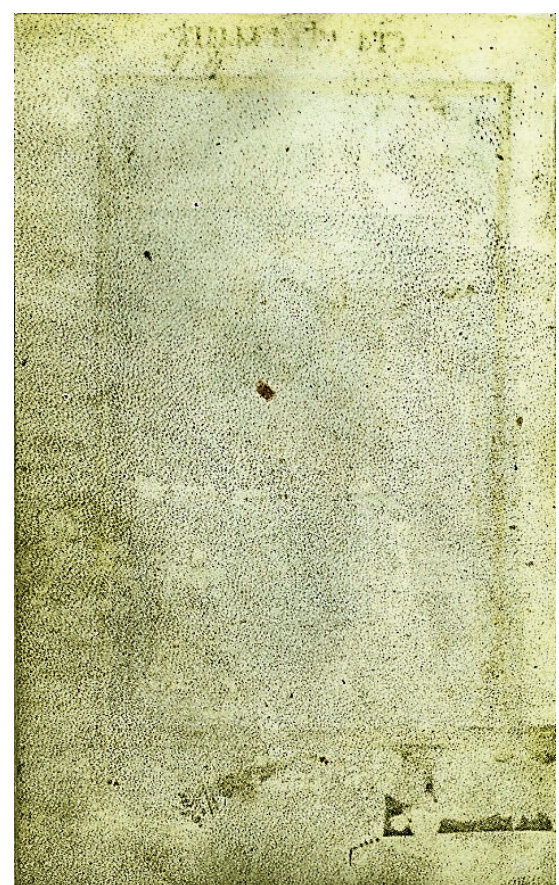

$3 a$

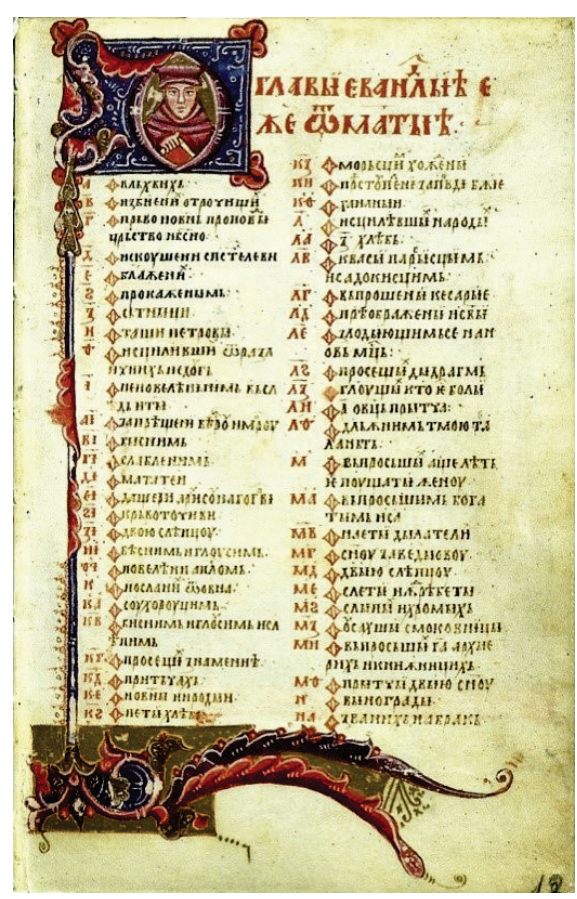

$3 b$

Slika 3. Otisak motiva s $13 r$ na $6 v$

također i izgleda, sadržaja i poretka tekstova srednjovjekovnih rukopisa nastalih na ovom podneblju. Iako se Hvalov zbornik, kao i ostali srednjovjekovni bosanski rukopisi, ako izuzmemo Čajničko evanđelje, ne nalazi u Bosni i Hercegovini, mišljenja smo kako možemo biti zadovoljni načinom na koji se čuva u Univerzitetskoj biblioteci u Bolonji. 


\section{Literatura}

- $\quad$ Antonino, Biancastella. 2004. "Il respire del Pasato dai fondi della Biblioteca Universitaria di Bologna" Alumina PAGINE MINIATE: 26-31.

- Biblioteche d'Italia, le biblioteche pubbliche statali. 1991. Gaeta: Ministero per i beni culturalle e ambientali ufficio centrale pre i beni librari e gli instituti culturali, Gaetagrafiche srl.

- Brković, Milko. 2008. Hrvoje Vukčić Hrvatinić (1380.-1416.) u zrcalu vlastitih isprava. Sarajevo: Matica hrvatska.

- Ćošković, Pejo. 2005. Crkva bosanska u XV. stoljeću. Sarajevo: Institut za istoriju Sarajevo.

- Daničić, Đuro. 1871. "Hvalov rukopis" Starine 3: 1-146.

- Daničić, Đuro. 1872. “Apokalipsa iz Hvalova rukopisa" Starine 4: 86-109.

- Dobrowský, Josef. 1822. Institutiones linguae slavicae dialecti veteris, quae quum apud Russos, Serbos aliosque ritus graeci, tum apud Dalmatas Glagolitas ritus latini Slavos in libris sacris obtinet. Vindobonae: Sumtibus et Typis Antonii Schmid.

- Dragojlović, Dragoljub. 1981. "Apokalipse bosanskih krstjana i staroslovensko književno nasleđe" Književna istorija 3(52): 603-610.

- Dragojlović, Dragoljub. 1983. "Zbornik Krstjanina Hvala i problem 'crkve bosanske"" Balcanica 1314: 73-84.

- Dragojlović, Dragoljub. 1983a. "Biblijska književnost u srednjovekovnoj Bosni (II)" Književna istorija 16(62): 255-258.

- Dragojlović, Dragoljub. 1997. Istorija srpske književnosti u srednjovekovnoj bosanskoj državi. Novi Sad: Svetovi.

- Džaja, Srećko M., i Lovrenović, Dubravko. 2007. "Srednjovjekovna Crkva bosanska" Svjetlo riječi: $3-15$.

- Đurić, Vojislav J. 1957. "Minijature Hvalovog rukopisa" Istorijski glasnik 1-2: 39-51.

- Filipović, Emir. 2017. Bosansko kraljevstvo. Sarajevo: Mladinska knjiga.

- Fine, John V. A. Jr. 2005. Bosanska crkva: novo tumačenje: Studija o Bosanskoj crkvi, njenom mjestu u državi i društvu od 13. do 15. stoljeća. Sarajevo: Bosanski kulturni centar.

- Glušac, Vaso. 1924. "Srednjovjekovna 'bosanska crkva' bila je pravoslavna?" Prilozi za jezik, književnost, istoriju i folklor: 1-55.

- Glušac, Vaso. 1945. Istina o bogomilima, istorijska rasprava. Beograd: štamparija Luč.

- Hamm, Josip. 1960. "Apokalipsa bosanskih krstjana” Slovo 9-10: 43-104.
- Harisijadis, Mara. 1988. "Iluminacija rukopisa bosanskog porekla u Srednjem veku" Glas CCCLIV Srpske akademije nauka i umetnosti 6(198): 91143.

- Jurić-Kappel, Jagoda. 2012. "Sistem žanrova u srednjovjekovnoj bosanskoj vjerskoj pismenosti/ književnosti" U Bosanskohercegovački slavistički kongres I: knjiga I, Zbornik radova / lingvistika, uredio Senahid Halilović, 87-99. Sarajevo: Slavistički komitet u BiH.

- Kardaš, Mehmed, i Erma Ramić Kunić. 2018. “Katalog rukopisa bosanske crkvenoslavenske pismenosti" Kirilometodievistika 12(18): 117-157.

- Klaić, Vjekoslav. 1927. "Herceg Hrvoje i Hval krstjanin” Nastavni vjesnik: časopis društva hrvatskih srednjoškolskih profesora 35: 83-88.

- Kreigher-Hozo, Metka. 2007. Metode slikanja i materijali, prošireno izdanje. Sarajevo: Kult.

- Kuna, Herta, i Jovanka Maksimović. 1986. CODEX "CHRISTIANI" nominee Hval, Zbornik Hvala krstjanina: transkripcija i komentar. Sarajevo: Svjetlost.

- Kuna, Herta. 2008. Srednjovjekovna bosanska književnost. Forum Bosnae 45. Sarajevo: Međunarodni Forum Bosna.

- Kukuljević Sakcinski, Ivan. 1857. Izvjestje o putovanju kroz Dalmaciju u Napulj i Rim, sa osobitim obzirom na slavensku književnost, umjetnost $i$ starine. Zagreb: Narodna tiskarnica Dra. Ljudevita Gaja.

- $\quad$ Lovrenović, Dubravko. 2000. "Vitez, herceg i pataren: Ideološki stereotipi i životna stvarnost" Forum Bosnae 7-8: 257-294.

- Lovrenović, Dubravko. 2006. Na klizištu povijesti (sveta kruna ugarska i sveta kruna bosanska 13871463). Zagreb - Sarajevo: Synopsis - Zoro.

- Maksimović, Jovanka. 1983. Srpske srednjovekovne minijature. Beograd: Prosveta.

- Maksimović, Jovanka. 1997. "Rukopisi i minijaturno slikarstvo" (poglavlje "Umetnost u doba bosanske srednjovekovne države") Zbornik za istoriju Bosne i Hercegovine: 53-70.

- Maksimović, Jovanka. 1976. "Slikarstvo minijatura u srednjovekovnoj Bosni” Zbornik radova Vizantološkog instituta 17: 175-188.

- MacRobert, Mary Catherine, i Lejla Nakaš. 2012. Bosanski psaltir iz Zbornika Hvala krstjanina. Forum Bosna 60. Sarajevo: Međunarodni Forum Bosna.

- $\quad$ Malcolm, Noel. 1995. Povijest Bosne. Zagreb - Sarajevo: Novi Liber - Dani.

- Mandić, Dominik. 1962. Bogomilska crkva bosanskih krstjana. Chicago: The Croatian Historical Institute. 
- Mazrak, Ema. 2016. “O uzorima minijaturiste Hrvojevog misala” Bosna Franciscana 44: 17-50.

- Mikulić, Planinka. 2004. Iz likovnosti bosanskoga srednjovjekovlja. Sarajevo - Zagreb: Zoro.

- Muzzioli, Giovanni. 1954. "Miniatura orientale e bizantina" Mostra storica nazionale della miniature, Catalogo: 19 .

- $\quad$ Nakaš, Lejla. 2018. Paratekstualnost u srednjovjekovnoj bosanskoj književnosti. Forum Bosnae 8384. Sarajevo: Međunrodni forum Bosna.

- Nazor, Anica. 2005. "Rukopisi Crkve bosanske" U Fenomen "krstjani" u srednjovjekovnoj Bosni $i$ Humu, zbornik radova, uredio Franjo Šanjek, 540541. Sarajevo - Zagreb: Institut za istoriju - Hrvatski institut za povijest.

- $\quad$ Nikolajević, Ivanka. 1997. "Minijatura Blagovesti u Hvalovom zborniku” Zograf: časopis za srednjovekovnu umetnost 7: 75-77.

- Petranović, Božidar. 1867. Bogumili, Crkva bosanska i krstjani. Zadar: Pečatnja Demarki-Ružier.

- Petrović, Leon. 1999. [1953.] Kršćani Bosanske crkve. Sarajevo - Mostar: Svjetlo riječi - ZIRAL.

- Petrović, Radmil. 2008. Bogumili. Beograd: Pešić i sinovi.
- Rački, Franjo. 1869. "Prilozi za povijest bosanskih patarena" Starine 1: 105-113.

- Radojčić, Svetozar. 1950. Stare srpske minijature. Beograd: Naučna knjiga.

- Radosavljević, Vera. 1984. Tehnika starog pisma $i$ minijature. Beograd: Narodna biblioteka Srbije Republički zavod za zaštitu spomenika kulture.

- Rodriquez, Ferdinando. 1956. Di alcuni codici miniati della biblioteca universitaria di Bologna. Bologna: Tipografia Luigi Parma.

- Solovjev, Aleksandar. 1948. "Vjersko učenje Bosanske crkve" Rad JAZU 270: 5-46.

- Šanjek, Franjo. 2000. "Krstjani' crkve bosanske" Radovi 32-33: 423-429.

- Šanjek, Franjo. 2003. Bosansko-humski krstjani u povijesnim vrelima (13.-15. st.). Zagreb: Barbat.

- $\quad$ Šidak, Jaroslav. 1975. Studije o 'Crkvi bosanskoj' $i$ bogumilstvu. Zagreb: Sveučilišna naklada Liber.

- Vrana, Vladimir. 1942. "Književna nastojanja u sredovječnoj Bosni” U Draganović, Krunoslav et al. Poviest hrvatskih zemalja Bosne $i$ Hercegovine: Od najstarijih vremena do godine 1463, knjiga I, 794822. Sarajevo: Napredak.

\title{
NEW FINDINGS RELATING TO HVAL'S MISCELLANY
}

\begin{abstract}
This article sets out the results of a study of one of the finest manuscripts of mediaeval Bosnia - Hval's Miscellany, conducted in the University Library in Bologna. A synthetizing overview of studies to date and comparative analysis of the original and facsimile editions were used to detect and reinterpret certain problematic areas relating to the Miscellany. First to be addressed is the latest treatment and storage of the codex in the Library. This is followed by a critical approach to the evaluation of the original manuscript as compared with the facsimile. A separate chapter deals with the sequence of the folios in Hval's Miscellany, the collaboration of two miniaturists, and the technical aspects of illumination.
\end{abstract}

Keywords: Hval's Miscellany, Hval, original, facsimile, library, sequence of the folios, illumination 